\section{Mr. J. J. JoICey}

Mr. James John Joicex, who died early in March, aged sixty-one years, was the founder of the Hill Museum and also a munificent benefactor of the Natural History Museum, South Kensington.

Mr. Joicey started to form a collection of British butterflies and moths at quite an early age, but it was not until his interest in exotics was aroused that there appeared much likelihood of his adding appreciably to the sum of human knowledge. In 1910 he acquired the collection formed by Henley Grose-Smith, an ardent disciple of W. C. Hewitson, and two years later added to it the Herbert Druce collection. These two collections, both rich in type material from all parts of the world, were so extensive that extra accommodation had to be built to house them. The Hill Museum was thus established in 1913. Through the exertions of collectors employed by Mr. Joicey from this time onwards, remarkable collections were sent home to him from Peru, the Amazon valley, Dutch New Guinea, Waigeu, the Schouten Islands, many other of the less-known islands of the Dutch East Indies, Yunnan, Hainan, and Central Africa. All these were rich in new material, or shed light upon the geographical distribution of the Lepidoptera.

The scientific results were published from time to time in various journals, but mainly, from 1921 onwards, in the Bulletin of the Hill Museum, which, during its eleven years' existence, has run to four handsome and richly illustrated volumes, to which, no doubt, would have been added many others had not Mr. Joicey's enthusiasm for his subject outrun his ability to meet the expenses. Between 1914 and 1930 about sixty papers by Mr. Joicey, in collaboration with others, were listed in the titles in the "Zoological Record".

Besides employing collectors, Mr. Joicey acquired by purchase many valuable collections, notably those of Roland Trimen, H. J. Elwes, Col. Swinhoe, Hamilton Druce, Wichgraf, Riffarth, and others, all rich in types. A catalogue of the type specimens of Rhopalocera in the Hill Museum had just been completed, and all arrangements made for its publication, a few days before Mr. Joicey's death. This, better than anything else, will indicate the value of the contents of the Hill Museum, at least from a taxonomic point of view ; the total number of type specimens enumerated is 2724 . In the moths, the types were probably even more numerous relatively, as they had been worked fairly thoroughly by many specialists, but as they have not been catalogued, it is not possible to give definite information. Two years ago it was estimated that Mr. Joicey's museum contained approximately four hundred thousand specimens, including about five thousand types; but for some years prior to that, large sections of it, with which it was found impossible to cope at Witley, had been presented to the British Museum (Natural History) from time to time, with results highly beneficial to the remaining collection, in that the staff under Mr. Talbot's capable direction was able to maintain it in really excellent order and thoroughly up to date throughout.
The closing of the Hill Museum and the disbanding of its staff are events which will have serious repercussions throughout the ranks of lepidopterists in all parts of the world, and will definitely slow up the rate of advance in this much favoured though, we fear, often despised branch of science.

In addition to his intense keenness on butterflies and moths, Mr. Joicey had a wide general interest in natural history, was an excellent game shot, an enthusiastic fisherman, and a very successful amateur gardener. His collection of orchids contained many rarities and had brought him quite a number of prizes.

\section{Sir William Smith}

Sir William Robert Smith, who died suddenly on March 17, aged eighty-two years, commenced his career at the age of fifteen years as assistant to a chemist, but so well did he use his opportunities that he was able to enter the medical school of St. Bartholomew's Hospital and later to complete his medical studies at Edinburgh, where he obtained the double qualification of the Colleges in 1871. He afterwards graduated M.D. at Aberdeen and D.Se. in public health at Edinburgh, and became a barrister-at-law. He was keenly interested in polities-contesting some of the Scottish university seats - and in academic and civic life.

It was in the domain of public health that William Smith made his mark. He was for several years medical officer to the old School Board for London and director of the public health laboratories in King's College, London. He afterwards became professor of forensic medicine in King's College and Hospital Medical School, succeeding the late Sir David Ferrier in this office, and found time to edit the seventh edition of Guy and Ferrier's standard textbook of forensic medicine. $\mathrm{He}$ was a member for many years, and vice-chairman 1910-13, of the old Metropolitan Asylums Board.

William Smith will be remembered for his insistence that a special diploma in public health should be a necessary qualification for the medical officer of health of the larger districts, and the institution of the diploma in public health was largely owing to his efforts. For many years he had been principal of the Royal Institute of Public Health, of which he was the virtual founder, and only recently had completed a scheme for the removal of the Institute to a new site in Queen's Square, and had just lived to see the erection of the skeleton of the new building there. He was a good speaker and able controversialist, and the congresses of the Royal Institute of Public Health at home and abroad owed much of their success to his great capacity as an organiser. R. T. H.

$W_{\mathrm{E}}$ regret to announce the death, at the age of eighty-four years, on March 25, of Prof. Rushton Parker, professor of surgery in University College and the University of Liverpool since 1882. Prof. Parker practised and taught surgery since 1869 , and was among the first to practise Lister's system of antiseptic surgery. For many years he was consulting surgeon to the Liverpool Royal Infirmary and Bootle General Hospital. 